\title{
Research on the relationships between destination image, perceived value and tourism experience of gastronomy tourism-- A case of Macao Food Tourists
}

\author{
Yan $\mathrm{Lu}^{1, *}$, Yue $\mathrm{Hu}^{2}$ \\ ${ }^{1}$ Institute for Research On Portuguese-Speaking Countries, City University of Macao, 999078 Macao, China \\ ${ }^{2}$ Faculty of Business, City University of Macao, 999078 Macao, China
}

\begin{abstract}
Gastronomy tourism, as a new tourism mode with special interest, can not only stimulate tourists' interest in experiencing local traditional food, but also better meet tourists' personalized experience needs, which is highly respected by the tourism market. Based on the research of scholars at home and abroad, this paper takes Macao food tourists as the research object to study the relationship among tourism experience, perceived value and destination image. The results show that the tourism experience of Macao food tourists has a significant positive impact on their perceived value and destination image, while the perceived value of tourists has a significant positive impact on their destination image. Based on the above research results, this paper puts forward several suggestions for the sustainable development of Macao's gastronomy tourism and makes a little contribution to the development of Macao's gastronomy tourism.
\end{abstract}

\section{Introduction}

Nowadays, the homogenization of tourism is very serious. Diversity, difference and special interest tourism can not only bring meaningful tourism experience to tourists, but also reduce the damage to tourism destinations and make the development of tourism more sustainable[1]. Gastronomy tourism, as a part of special interest tourism, has gradually become the first choice for people to travel. At the beginning of the 21st century, the related research on gastronomy tourism officially arose and soon became the focus of academic research. Many scholars have classified gastronomy tourism as a kind of tourism activity[2-3], a kind of travel behavior[4-6], a process of enjoyment and experience[7] and an important way of leisure and entertainment[8]. The purpose of gastronomy tourism is to find and enjoy delicious food and bring unforgettable gourmet experience, and to taste food with local cultural characteristics during gastronomy tourism[2]. Tourists' tourism experience and perceived value in the process of gastronomy tourism will affect their overall impression, belief, thoughts, expectations and emotions of the tourism destination.

Macao is an international free port and one of the cities with the most developed tourism. At present, there are few related researches on Macao's gastronomy tourism and they have not kept pace with the development of gastronomy tourism, which leads to tourism developers unable to grasp the market situation and understand the market demand, thus making the function and effect of gastronomy tourism unable to be demonstrated. By combing the object elements of gastronomy tourism destination image, this paper discusses the impact of perceived value and tourism experience on it and constructs a hypothetical model. Taking Macao food tourists as an example, this paper makes an empirical study and puts forward suggestions for the development of Macao gastronomy tourism.

\section{Materials and Methods}

\subsection{Research hypothesis}

Based on the research of Kang and Gretzel, $\mathrm{Wu}$ and Feng, Long and $\mathrm{Wu}$, this paper divides tourism experience into learning experience, enjoying experience, emotional experience and sensory experience, and collects tourists' feelings from different aspects[13-15]. Court and Lupton found through empirical research that tourists' experience will have a significant impact on the image of the tourist destination[9]. Shen et al.took Huashan Coffee in Gukeng Township of Taiwan as the research object to explore the relationship between tourism experience and destination image. The study found that the emotional experience and sensory experience of Huashan coffee tourists have the greatest influence on the composition of tourists' destination image[10]. Goodrich found when studying the relationship between destination perception and destination preference that the better the tourist's perception of the destination, the more likely the destination is to become the tourist's tourist destination ${ }^{[1]}$. In other words, tourists' perceived value will affect the destination image, thus affecting tourists' behavioral intention. After that, Zhao et al.took hot spring tourism as

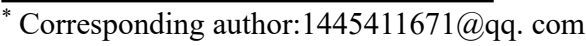


an example to conduct research. The results show that the perceived value evaluates the destination after weighing the "benefits" and "losses" in the process of tourism experience. The greater the perceived value of tourists, the deeper the impression of their destination on tourists[12]. According to the above literature and in combination with this paper, a conceptual model (as shown in Figure 1) is constructed and the following assumptions are put forward:

H1 : Tourists' tourism experience has a significant positive impact on tourists' perceived value.

$\mathrm{H} 2$ : Tourists' tourism experience has a significant positive impact on tourists' destination image.

H3: Tourists' perceived value has a significant positive impact on tourists' destination image.

The research model in this paper is shown in Figure 1:

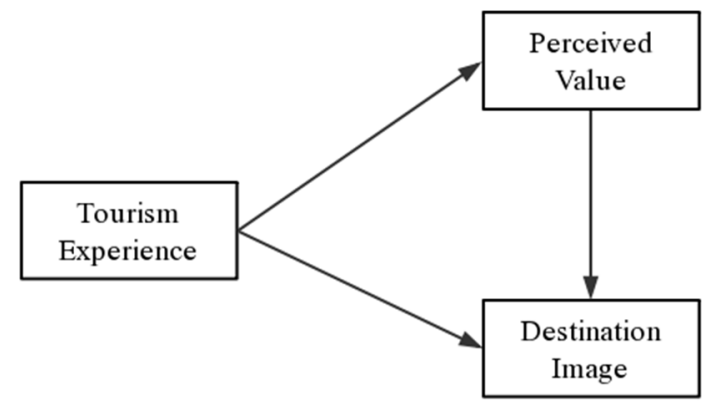

Fig. 1. Research framework

\subsection{Research Design}

\subsubsection{Data and Sample}

This study takes Macao food tourists as the research object, through on-the-spot investigation, it is found that Macao Guanye Street, Macao Broadway Gourmet Street, Macao Sanzhandeng Gourmet Street, Macao October 5th Street, Macao Kanggong Night Market, Macao Xinma Road Gourmet Street, Macao Luhuan Gourmet Street and Dasanba Gourmet Street are the eight places where Macao's local special delicacies gather. The number of tourists is large, and it is easier to come into contact with tourists whose main purpose is delicious food. In this study, 489 questionnaires were distributed and 489 questionnaires were collected. After deleting the contents of the items, the answers were incomplete or the results showed consistent answers, and 79 invalid questionnaires were screened to fill in no items, 410 valid questionnaires were obtained, with an effective recovery rate of $83.84 \%$.

\subsubsection{Measures}

In this study, the variables were measured on the basis of the existing mature scales. In order to verify the above hypothesis, this paper adopts Likert 7-point scoring method to measure the relevant variables, and empirically tests the data obtained from the questionnaire survey.

Tourism Experience: The measurement of tourism experience of Macao gourmet tourists is based on relevant documents of Kang and Gretzel(2012)[13], Wu and
Feng(2018)[14] and Long and Wu (2009)[15], totaling 9 questions. In this study, Cronbach's $\alpha=0.935$.

Perceived Value: Measurement of Perceived Value of Macao Food Tourists. This part refers to relevant documents of Wang et al.(2014)[16]and Wu and Feng (2018)[14], totaling 15 questions. In this study, Cronbach's $\alpha=0.947$.

Destination Image: Measurement of Destination Image of Macao Food Tourists. This part refers to relevant literatures of Baloglu and McCleary (1999)[17], Chen et al.(2017)[18], totaling 17 questions. In this study, Cronbach's $\alpha=0.954$.

Control variables: demographic characteristics of Macao food tourists, including gender, age, occupation, income, educational background, number of peers, daily residence, sources of Macao food-related information, and daily consumption amount of each person on food and beverage during Macao tourism, totaling 9 questions.

\section{Results \& Discussion}

\subsection{Correlation analysis}

Table 1. Feasibility Correlation Analysis of Tourists' Tourism Experience, Perceived Value and Destination Image

\begin{tabular}{|c|c|c|c|c|}
\hline & & $\begin{array}{c}\text { Tourism } \\
\text { experience }\end{array}$ & $\begin{array}{l}\text { Perceived } \\
\text { value }\end{array}$ & $\begin{array}{c}\text { Destination } \\
\text { image }\end{array}$ \\
\hline \multirow{3}{*}{$\begin{array}{c}\text { Tourism } \\
\text { experience }\end{array}$} & Pearson & 1 & $.785^{* *}$ & $.739 * *$ \\
\hline & $\begin{array}{l}\text { Significance } \\
\text { (double tails) }\end{array}$ & & .000 & .000 \\
\hline & $\mathrm{N}$ & 410 & 410 & 410 \\
\hline \multirow{3}{*}{$\begin{array}{l}\text { Perceived } \\
\text { value }\end{array}$} & Pearson & $.785 * *$ & 1 & $.883 * *$ \\
\hline & $\begin{array}{l}\text { Significance } \\
\text { (double tails) }\end{array}$ & .000 & & .000 \\
\hline & $\mathrm{N}$ & 410 & 410 & 410 \\
\hline \multirow{3}{*}{$\begin{array}{l}\text { Destination } \\
\text { image }\end{array}$} & Pearson & $.739 * *$ & $.883 * *$ & 1 \\
\hline & $\begin{array}{l}\text { Significance } \\
\text { (double tails) }\end{array}$ & .000 & .000 & \\
\hline & $\mathrm{N}$ & 410 & 410 & 410 \\
\hline
\end{tabular}

Note: **. The correlation was significant on level 0.01 (double tails)

From Table 1, it can be seen that the correlation coefficient between tourists' tourism experience and tourists' perceived value is positive, reaching a significant level, indicating that there is a significant positive correlation between tourists' tourism experience and tourists' perceived value; The correlation coefficient between tourists' tourism experience and tourists' destination image is positive, reaching a significant level, indicating that there is a significant positive correlation between tourists' tourism experience and tourists' destination image; The correlation coefficient between tourists' perceived value and tourists' destination image is positive, reaching a significant level, indicating that there is a significant 
positive correlation between tourists' perceived value and tourists' destination image.

\subsection{Regression analysis}

\subsubsection{Regression Analysis of Tourists' Tourism Experience to Tourists' Perceived Value}

The regression model of tourists' tourism experience to tourists' perceived value is shown in the following table:

Table 2. Data Analysis of Regression Model between Tourists' Tourism Experience and Perceived Value

\begin{tabular}{cccccccc}
\hline \multicolumn{1}{c}{ After } & \multicolumn{2}{c}{ Standard } \\
Model & $\mathrm{R}$ & $\mathrm{R}^{2}$ & $\mathrm{R}^{2}$ & Edror & $\mathrm{F}$ & Significance \\
\hline 1 & $.785 \mathrm{a}$ & .616 & .615 & .55703 & 653.126 & $.000 \mathrm{~b}$ \\
\hline
\end{tabular}

Note: a. Dependent Variable: tourists' perceived value;

b. Forecast variables: (constant), tourists' travel experience.

Table 3. Coefficients of Regression Model between Tourists' Tourism Experience and Perceived Value

\begin{tabular}{|c|c|c|c|c|c|}
\hline \multirow[b]{3}{*}{ Model } & \multicolumn{2}{|c|}{$\begin{array}{c}\text { Non- } \\
\text { normalized } \\
\text { coefficient }\end{array}$} & \multirow{2}{*}{$\begin{array}{c}\begin{array}{c}\text { Normalization } \\
\text { coefficient }\end{array} \\
\end{array}$} & \multirow[b]{3}{*}{$\mathrm{T}$} & \multirow[b]{3}{*}{ Significance } \\
\hline & & tandarc & & & \\
\hline & $\mathrm{B}$ & Error & Beta & & \\
\hline 1 (Constant) & 1.286 & .165 & & 7. 811 & .000 \\
\hline $\begin{array}{c}\text { Tourists' } \\
\text { Travel } \\
\text { Experience }\end{array}$ & .741 & .029 & .785 & 25.556 & .000 \\
\hline
\end{tabular}

As can be seen from the above table, $\mathrm{F}=653.126$, which tests the regression effect, shows that the regression equation has a high degree of fitting. Under the confidence level of $0.001, \mathrm{P}=0.000$, which helps the regression analysis of the model to show significant phenomena. The correlation coefficients of this regression analysis are $\mathrm{R}^{2}=0.616, \mathrm{~T}=25.556, \mathrm{P}=0.000$, which help tourists to have a significant correlation between tourism experience and tourists' perceived value.

To sum up, Assumption 1: Tourists' tourism experience has a significant positive impact on tourists' perceived value, which has been verified.

\subsubsection{Regression Analysis of Tourist Experience to Tourist Destination Image}

The regression model of tourists' tourism experience to tourists' destination image is shown in the following table:

Table 4. Data Analysis of Regression Model between Tourists' Tourism Experience and Destination Image

\begin{tabular}{cccccccc}
\hline \multicolumn{7}{c}{ After } & \multicolumn{2}{c}{ Standard } \\
Model & $\mathrm{R}$ & $\mathrm{R}^{2}$ & $\mathrm{R}^{2}$ & Error & $\mathrm{F}$ & Significance \\
\hline 1 & $.739 \mathrm{a}$ & .546 & .545 & .66339 & 491.041 & $.000 \mathrm{~b}$ \\
\hline
\end{tabular}

Note: a. Dependent Variable: tourists' destination image; b.Forecast variables: (constant), tourists' travel experience.

Table 5. Coefficient of Regression Model between Tourists' Tourism Experience and Destination Image

\begin{tabular}{|c|c|c|c|c|c|}
\hline \multirow[b]{3}{*}{ Model } & $\begin{array}{r}1 \\
\text { nor } \\
\text { coe }\end{array}$ & $\begin{array}{l}\text { on- } \\
\text { alized } \\
\text { icient }\end{array}$ & $\begin{array}{c}\text { Normalization } \\
\text { coefficient }\end{array}$ & \multirow[t]{3}{*}{ n } & \multirow[b]{3}{*}{ Significance } \\
\hline & \multicolumn{2}{|c|}{ Standard } & \multirow[b]{2}{*}{ Beta } & & \\
\hline & B & Error & & & \\
\hline 1 (Constant) & .884 & .196 & & 4.505 & .000 \\
\hline $\begin{array}{c}\text { Tourists' } \\
\text { Travel } \\
\text { Experience }\end{array}$ & .765 & .035 & .739 & 22.159 & .000 \\
\hline
\end{tabular}

From the above table, it can be seen that $\mathrm{F}=491.041$, which shows that the regression equation has a high fitting degree. Under the confidence level of $0.001, \mathrm{P}=0.000$, which helps the regression analysis of the model to show significant phenomena; The correlation coefficients of this regression analysis are $\mathrm{R}^{2}=0.546, \mathrm{~T}=22.159, \mathrm{P}=0.000$, which help tourists to have a significant correlation between tourism experience and tourists' destination image.

To sum up, Assumption 2: Tourists' tourism experience has a significant positive impact on tourists' destination image through verification.

\subsubsection{Regression Analysis of Tourists' Perceived Value to Tourists' Destination Image}

The regression model of tourists' perceived value to tourists' destination image is shown in the following table:

Table 6. Data Analysis of Regression Model between Tourists' Perceived Value and Destination Image

\begin{tabular}{lcccccc}
\hline \multicolumn{6}{c}{ After } & \multicolumn{2}{c}{ Standard } \\
Model & $\mathrm{R}$ & $\mathrm{R}^{2}$ & $\mathrm{R}^{2}$ & Edjustment & $\mathrm{F}$ & Significance \\
\hline 1 & $.883 \mathrm{a}$ & .779 & .778 & .46298 & 1437.835 & $.000 \mathrm{~b}$ \\
\hline Note: a. Dependent Variable: tourists' destination image; & \\
b. Predictive variables: (constant), tourists' perceived value.
\end{tabular}

Table 7. Coefficients of Regression Model between Tourists' Perceived Value and Destination Image

\begin{tabular}{lllllll}
\hline \multicolumn{1}{c}{$\begin{array}{c}\text { Non- } \\
\text { normalized } \\
\text { coefficient }\end{array}$} & $\begin{array}{c}\text { Normalization } \\
\text { coefficient }\end{array}$ & & \\
\cline { 2 - 5 } Model & $\mathrm{B}$ & $\begin{array}{c}\text { Standard } \\
\text { Error }\end{array}$ & Beta & $\mathrm{T}$ & Significance \\
\hline 1 (Constant) & -.091 & .141 & & -.644 & .520 \\
& $\begin{array}{c}\text { Perceived } \\
\text { Value }\end{array}$ & .805 & .021 & .883 & 37.919 & .000 \\
\hline
\end{tabular}

Note: a. Dependent Variable: tourists' destination image;

b. Predictive variables: (constant), tourists' perceived value.

From the above table, it can be seen that $\mathrm{F}=1437.835$, which shows that the regression equation has a high degree of fitting. Under the confidence level of 0.001 , $\mathrm{P}=0.000$, which helps the regression analysis of the model 
to show significant phenomena; The correlation coefficients $\mathrm{R}^{2}=0.779, \quad \mathrm{~T}=37.919, \mathrm{P}=0.000$ of this regression analysis help tourists' perceived value to have a significant correlation with tourists' destination image.

To sum up, Assumption 3: Tourists' perceived value has a significant positive impact on tourists' destination image, which has been verified.

\section{Conclusions}

This study explores the relationship among tourism experience, perceived value and destination image of Macao gourmet tourists. The results show that the tourism experience of Macao gourmet tourists has a significant positive impact on their perceived value; The tourist experience of Macao gourmet tourists has a significant positive impact on their destination image. Tourists' perceived value has a significant positive impact on tourists' destination image.

\section{References}

1. Ling,Q.Q., Zhou,L. (2009)Research progress of wine tourism abroad. J.Tourism Tribune.,6:85-92.

2. Wolf,E. (2002)Culinary tourism: A tasty economic proposition.J.Retrieved October 8,2019,from http://www.culinarytourism.org.

3. Chi,J.C.(1998) Exploration of tourism economy in 20 years of reform and development. Guangdong Publishing, Guangzhou.

4. Hall,C.M.,Sharples,L.,Mitchell,R.,Macionis,N.,Cam bourne,B.(2004) Gastronomy tourism around the world. Routledge Publishing,London.

5. Wang,X.L.,Wu,Z.J.,Zhong,Y.(2007)Gastronomy tourism Market Demand Analysis -- Taking Guilin World Gourmet Expo Park as an Example.J. Journal of Leshan Teachers College. ,5:55-58.

6. Guan,J.J.(2012)A review of foreign research on food and tourism -- and the generalization of gastronomy tourism concept.J. Tourism Tribune. ,10:85-91.

7. Long,L.(2004)Culinary Tourism.The University Press of Kentucky,Lexington.

8. Wu,X.D.,Kang,J.(2010)Discussion on the development of local gastronomy tourism in China based on the needs of tourists.J.Jiangsu Commercial Forum.,6:49-51.

9. Court,B.,Lupton,A.R.(1997)Customer portfolio development: modeling destination adopters, inactives and rejecters.J.Journal of Travel Research.,36(1):35-36.

10. Shen,J.C.,Miao,R,C.,Zhou,J.Y.(2005)A Study on the Influence of Tourist Experience, Tourist Image, Satisfaction and Loyalty: A Case Study of Huashan Coffee.J.Journal of Outdoor Recreation Study.,18(3):43-56.

11. Goodrich,J.N.(1978)The relationship between preferences for and perceptions of vacation destination:Application of a choice model.J.
Journal of Travel Research.,17(2):8-13.

12. Zhao,J.Y.,Ma,P.,Lu,Z.Y.(2013)The relationship between destination image,perceived value and tourist loyalty of hot spring tourism: A case study of Tanggangzi in Liaoning Province.J.Enterprise Economy.,(3):129-132.

13. Kang,M.,Gretzel,U.(2012)Effects of podcast tours on tourist experiences in a national park.J.Tourism Management.,33(2):440-455.

14. Wu,C.B.,Feng,A.R.(2018)Study on the Perception and Experience of Dalian Tourist Cate.J.Resource Development and Market. ,34(12):1771-1776.

15. Wu,H.J.,Long,Z.J.(2009)Theoretical model of tourism experience generation approach.J.Social Science Journal.,31(3):46-49.

16. Wang,L.,Zhang,H.M.,Lu,L.,Cai,L.P.,Yang,Z.Y.(2014 )Research on Visitor Perceived Value of Wetland Park -- A Case Study of Xixi/Qinhu Lake.J.Tourism Tribune.,29(6):87-96.

17. Baloglu,S.,McCleary,K.W.(1999)A model of destination image formation.J.Annals of Tourism Research.,26(4):868-897.

18. Chen,H.,Mei,Q.,Wang,Y.C.,Zhang,B.,Li,S.(2017)Th e driving effect of tourism image on environmental responsibility behavior in historic districts: with satisfaction as a mediating variable.J.China Population Resources and Environment.,27(12):106116. 